\title{
A NOTE ON THL USE OF BUSINESSMEN AS SUBJECTS IN SEALED OFFER MARKETS
}

\author{
Douglas V. DEJONG and Robert FORSYTHE* \\ University of lowa, lowa City, IA 52242, USA \\ Wilfred C. UECKER* \\ Rice University, Houston, TX 77251, USA
}

Received March 1985, final version received October 1986

\begin{abstract}
Using the data from sealed offer laboratory markets, we compure the price and quality choives of student subjects with those of businessmen subjects. The busisessmen subjects were =ublic accounting firm partners and corporate financial offsers. Thic is of interest since the financial officer-auditor relationship is one particular application of the elementary principal-agent modei which the laboratory environment was designed to test. Using several different performance measures we are unable to reject the null hypothesis that the average performance of the two subject pools were the same. However, the market using businessmen subjects generally exhibited greater variance than the market using students.
\end{abstract}

\section{Introduction}

In this note, we examine the behavior of businessmen as subjects in a laboratory market and compare their behavior with the behavior of student subjects in a similar market. This analysis allows us to begin to address the criticism frequently made about the study of laboratory processes that 'real' businessmen do not behave the same as student subjects in experiments. ${ }^{1}$ As Plott (1982, p. 1522) points out, this criticism is really a hypothesis about the

\footnotetext{
*We would like to thank the Department of Accounting for their financial support and the members of the Professuonal Accounting Councii of the Department of Accounting at the University of Iowa for their participation in the experiment. We would like to thank Al Schepanski for his comments. We would also like to thank Russell Lundholm and Jeffrey Schatzberg for their comments on earlier drafts of this paper and their assistance in conducting the experiments and analyzing the data. Funding for DeJong was provided, in part, by the Arthur Young Facuity Feilow Program in the Department of Accounting at the University of lowa. Partial suppret for Forsyothe was provided by NSF grant SES-85i,0539.

'This criticism is based on the findings of several studies of individual behavior using student subjects which are concerned with external validity issues. In general, the conclusions of these studies are that students cannot be used as surrogates for other groups such as businessmen [Alpert (i967), Khera and Benson (1970) and Hawkins, Albaum and Besi (1977)], and that student responses do not accurately reflect those of non-students [Cunningham, Anderson and Murphy (1974) and Shuptrine (1975)]. Our concern here, however, is not with externul validity, but rather whether difierent subject pools exhibit sifferent behavior in laboratory markets.
} 
behavior of $\mathrm{d}_{i}$ ferent subject pools (businessmen subjects vs. stcident subjects) and can be interpreted as a call for more experiments. However, due to time and location corstiaints, businessmen are very difficult to obtain. Furthermore, they are expensive subjects when they are obtained.

Recently, we had the opportunity to conduct two sealed offer markets which had identical laboratory market environments, i.e., the same procedures and parameters. One used businessmen as subjects and the other used students as subjects. With the data from these markets we will provide some initin: tests of the above hypothesis concerning the behavior of businessmen and students as subjects. ${ }^{2}$

In the next section, we provide a discussion of the laboratory markets we examined. In section 3, we give a brief presentation of the theoretical model on which these experiments were based. Our findings on the effect of subject pool variation are presented and discussed in section 4. A brief summary is given in the final section.

\section{The laboratory markets}

The laboratory environment here is the same as the one presented in DeJong, Forsythe and Uecker (1985), hereafter DFU. Both markets were based upon an elementary model of a principal-agent relationship and were designed to examine the effect of a negligence liability rule on the price and quality of services transacted. In these markets, each principal (buyer) had an opportunity to hire an agent (seller) to perform a service. The quality of the service provided by the agent was inversely related to the probability that the principal incurred a loss.

Each laboratory market involved seven subjects: three sellers with identical parameters and four buyers, also with identical parameters. The laboratory market involving student subjects required approximately three hours to complete. Because of time constraints, the laboratory market with businessmen as subjects lasted only two hours. Both laboratory markets consisted of a series of trading periods. At the beginning of a period, each seller submitted a sealed offer to each buyer to supply a specified quality of service

\footnotetext{
${ }^{2}$ Burns (1985) has also conducted a study which was designed to examine differences between professionals and students as subjects. She compared the price strategy choices of student subjects to those of highiy experienced wool buyers in a progressive oral auction market. While the laboratory market she conducted was similar to the wool market, it differed in several significant respects. Nontheless, the wool buyers reacted as if it were the 'real thing' and thus, their past experience led them to make decisiors which were no: profit maximizing. Without this preconditioning, students made prof $t$ maxirizing choices. However, neither subject pool received any rewards based upon thei' performance; they were simply told that 'the aim of the experiment is for you to attempt to muke as much profit as you can'. While we study a different market institution, we do provide rewards for subjects based upon their performance. Thus, any difference between Burns' results and ours may be due to institutional differences or to differences in the methods of payment.
} 
at a spuitied price. Each buyer could purck ase from at most one seller. After buyers received all of their offers, each buyer separately chose from which seller, if any, he wished to purchase. This information was then publicly disclosed, but the price and quality level agreed upon were not revealed. Buyers and sellers who had contracted for sirvices then determined whether or not a loss occurred by observing the outcome of a random draw from the probability distribution corresponding to the quality of service provided. Taking into account whether a loss occurred and who was liable for one if it did occur, buyers and sellers computed their profit for that trading period. They then proceeded to a new trading period which was a strict replication of the previous period(s).

Buth markets were conducted with a negligence liability rule. Under this rule, individual sellers were liable for a loss when the quality of service provided was less than a known due care standard. If the quality level provided met or exceeded the due care standard, the loss was borne by the buyer. The due care standard was sei at the level of service which minimized expected social costs for the parameters used (see section 3 and table 1).

In Market $S$ student subjects were used. These subjects were male sad female student volunteers in the College of Business ai the University of Iowa. In Market $B$, professional subjects were used. These subjects were all members of the Professional Accounting Council of the Department of Accounting at the University of lowa. This council is composed of partners from a number of public accounting firms and financial officers from a number of corporations. All had at least fifteen years of work experience and some had considerably more.

This professional subject pool was particularly interesting because one of the potential applications of the elementary principal-agent model presented in the next section is the market for audit services. In this market, the manager (principal) can hire an auditor (agent) to reduce the probability of a loss. A negligence liability rule also operates in this market. In particular, an auditor is held liable for the loss when he does not provide a 'due care' level of auditing. It is also common to have audit services obtained via a sealed offer institution.

The seven subjects we used from the council included five partners in public accounting (or auditing) firms and two corporate financial officers. We designated three council members, who were partners, as sellers and the four other council members, who were both partners and financial officcrs, as buyers. In the sealed offer institution, sellers are the active players who submit offers to buyers. Buyers are quite passive since they simply accept or reject the offers they receive. Thus, while it is unfortunate that we have only two corporate financial officers (managers) to use as buyers, we did have three partners (auditors) to use as sellers, i.e., the active side of the market.

For the student subjects, the value for the units being transacted was estab- 
lished by application of the theory of induced value [Smitl: (1976) and Piott (1979)]. At the beginning of each new trading period, the individual student buyers and sellers were provided with initial ex respectively. The parameter values used are given in tab: 1. As stated in the table, the potential loss faced by the buyer is $80 \%$. If the buyer does not purchase a unit, the probability that he incurs a loss is 0.90 . If he does make a purchase, the probability of the loss decreases as the quality of service increases. As stated earlier, the level of service which minimizes total expect $t$ cost is set as the due care standard. For the parameters presented in table 1 , this is the level of service which corresponds to a type 3 unit. At the conclusion of the market with student subjects, Market $S$, each subject was paid an amount in cash equal to the sum of their profits for all the trading periods. Payments ranged from approximately $\$ 10.00$ to $\$ 25.00$.

In the market with professional subjects, Market $B$, we wire concerned that the dollar amounts being paid to students would not be sufficient to motivate these subjects. To provide sufficient incentives for the professional subject pool, we adopted the 'duplicate method' for establishing value for the units being traded, which was originated by Kormendi and Plott (1982). We began the experiment by giving each subject a sealed envelope which contained the average trading period profits earned by subjects who had been 'similarly situated' in Market $S$. For example, in Market $B$, seller 1's envelope contained a slip of paper on which the average profits earned by seller 1 in Market $S$ had been written. Thus, each professional participant

Table 1

Parameter values for markets.

\begin{tabular}{|c|c|c|c|c|c|c|c|c|}
\hline $\begin{array}{l}\text { Level of } \\
\text { service } \\
\text { quality } \\
x\end{array}$ & $\begin{array}{l}\text { Probability } \\
\text { of loss } \\
P(x)\end{array}$ & $\begin{array}{l}\text { Expected } \\
\text { loss" } \\
P(x) l\end{array}$ & $\begin{array}{l}\text { Change } \\
\text { in } \\
\text { prob. } \\
\text { of loss } \\
\Delta P(x)\end{array}$ & $\begin{array}{l}\text { Change } \\
\text { in } \\
\text { expected } \\
\text { loss } \\
-\Delta P(x) l\end{array}$ & $\begin{array}{l}\text { Cost of } \\
\text { service } \\
C(x)\end{array}$ & $\begin{array}{l}\text { Change } \\
\text { in cost } \\
\Delta C(x)\end{array}$ & $\begin{array}{l}\text { Seller } \\
\text { expected } \\
\text { cost }^{\mathbf{b}}\end{array}$ & $\begin{array}{l}\text { Expected } \\
\text { social } \\
\text { cost }^{c}\end{array}$ \\
\hline $\begin{array}{l}\text { No } \\
\text { purchase } \\
1^{d} \\
3^{\text {e }} \\
5\end{array}$ & $\begin{array}{l}0.90 \\
0.60 \\
0.20 \\
0.05\end{array}$ & $\begin{array}{r}72 \phi \\
48 t \\
16 x \\
4 t\end{array}$ & $\begin{array}{l}-0.30 \\
-0.40 \\
-0.15\end{array}$ & $\begin{array}{l}24 t \\
32 \phi \\
12 \phi\end{array}$ & $\begin{array}{r}0 x \\
5 x \\
26 t \\
53 t\end{array}$ & $\begin{array}{r}5 \notin \\
21 \notin \\
27 \notin\end{array}$ & $\begin{array}{c}0 x \\
53 x \\
26 x^{e} \\
53 x\end{array}$ & $\begin{array}{l}72 k \\
53 k \\
42 c^{e} \\
57 t\end{array}$ \\
\hline
\end{tabular}

a'Loss $(l)=80$ throughout.

'Seller's expected cost when the seller bears liability for the loss is predicted to be $P(x) l+C(x)$. Seller's expected cost when the buyers bears liability for the loss is predicted to be $C(x)$. Under the assumption of risk neutrality, the fee, $r$, in a competitive mariket is predicitu is iyual the expected cost.

'Expected social cost is $P(x) l+C(x)$.

dSeller bears the loss under the negligence liability rule.

'Predicted equilibrium price and quality of service. This quality of service is also the due care standard and level of service that nimimizes expected social costs. 
was paired with a student who had oucupied the same position (i..., had the same parameters) in Market $S$. Subjects were not allowed to open their envelope until the conclusion of the market.

Each professional subject was told that he was playing for points (instead of money). If he succeeded in earning on average more points per trading perind than his student counterpart, he would receive a prize. (Each point corresponded to $1 \neq$ of the student's average earnings.) The prize was a University of Iowa pewter souvenir. If he failed to achieve average earnings that exceeded the student's average earnings, he would receive nothing. The reason for awarding a tangible prize instead of cash was twofold: First, we felt that a prohibitive amount of cash would be required if the induced reward structure was to dominate the businessmen's subjective participation costs. Second, we believed that by providing each successful subject with tangible evidence that he could use to show others that he had 'beaten the student' he was playing against, these subjects would have a sufficient inducement to try to earn as many points as they could. When interpreting the results reported in section 4 , it must be remembered that any tests of hypotheses regarding subject pool differences are nocessarily joint test s since they also depend upon the method of preference inducement.

\section{An elementary principal-agent model}

The model upon which these markets are based is described in detail in DFU. We will review it briefly. This model assumes competitive bshavior by risk neutral principals and agents who wish to maximize their respective expected wealths. The principal in this model is faced with a potential loss. By hiring an agent, the probability of a loss occurring is reduced depending upon the level of the agent's services. The agent's wealth in this situation is increased by his fee but is reduced by the services provided because such services are costly.

Let $l$ be the amount of the loss, $x$ the level (or quality) of service contracted for and provided by the agent, $r(x)$ the competively determiried fee which the principal pays to the agent for providing service level $x, C(x)$ the agent's cost of providing service of quality $x, P(x)$ the probability of a loss given service level $x$ has been provided.

Under a negligence liability rule, the agent is liable for the loss if he does not provide a due care level of service. That is, the agent's liability is $l$ if he does not meet the due care standard and the agent has no liability when he meets the due care standard. Under risk neutrality, Pareto optimality requires that the quality of services provided minimizes expected social cost, $C(x)+P(x) l$. Thus, the optimal level of service provided, $x^{*}$, is chosen such that marginal expected benefits equal marginal costs, i.e., 


$$
-P^{\prime}\left(x^{*}\right) l=C^{\prime}\left(x^{*}\right)
$$

where $P^{\prime}(\cdot)$ and $C^{\prime}(\cdot)$ represent the first derivatives of $P(\cdot)$ and $C(\cdot)$ with respect to $x$. For the parameters given in table $1, x^{*}$ corresponds to a type 3 quality level. Further, following a large body of literature in law and economics [e.g., Brown (1973), Shavell (1982)], we assume the courts set the due care standard optimality at $x^{*}$.

With the due care standard set at $x^{*}$, the agent's expected wealth is

$$
\begin{array}{ll}
r(x)-C(x)+P(x) l & \text { if } x<x^{*} \\
\eta(x)-C(x) & \text { if } x \geqq x^{*} .
\end{array}
$$

The agent is liable for the loss only in the event that a level of service below $x^{*}$ is provided and a loss occurs. With a competitive market, the agent's fee for a level of service $x$ will be $r(x)=C(x)+P(x) l$ if $x<x^{*}$ and $r(x)=C(x)$ if $x \geqq x^{*}$.

With these services priced competitively, the expected loss is internalized by the principal. Specifically, the principal's expected wealth is $-r(x)=$ $-C(x)-P(x) l$ if $x<x^{*}$ and $-r(x)-P(x) l=-C(x)-P(x) l$ if $x \geqq x^{*}$. Thus, the principal's expected wealth is given by $-C(x)-P(x) l$ and is maximized at the point where $-P^{\prime}(x) l=C^{\prime}(x)$, i.e., $x^{*}$. In equilibrium, the level of service demanded and provided is $x^{*}$ and the agent's fee is $r\left(x^{*}\right)=C\left(x^{*}\right)$. For the parameter values of table 1 , the equilibrium levei of service demanded and provided is a type 3 and the equilibrium fee is $26 \%$.

\section{Results}

The entire time series of transacted prices and qualities for Market $S$,

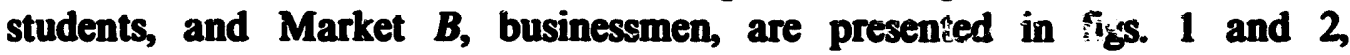
respectively. To facilitate comparisons across quality levels, the lower right panel in each figure gives the expected profit for each trade. Sellers' expected profit per trade is the fee received less the expected cost of the type provided, $C(x)$ for type 3 or 5 and $C(x)+P(x) l$ for a type 1 . Since we faced a two hour time constraint with the businessmen subjects, we were able to complete only twelve trading periods in Market $B$. Therefore, we confine our discussion and comparisons to the first twelve periods in each market. Furthermore, our focus is on the similarity of observed behavior between businessmen and students and not the consistency of the observed behavior with the predictions of the model. ${ }^{3}$

\footnotetext{
${ }^{3}$ The first twelve trading periods of a market do not provide a sufficient basis for drawing conclusions about the latter. For a full discussion of the consistency of the observed behavior of student subjects with the predictions of the model, see DFU.
} 

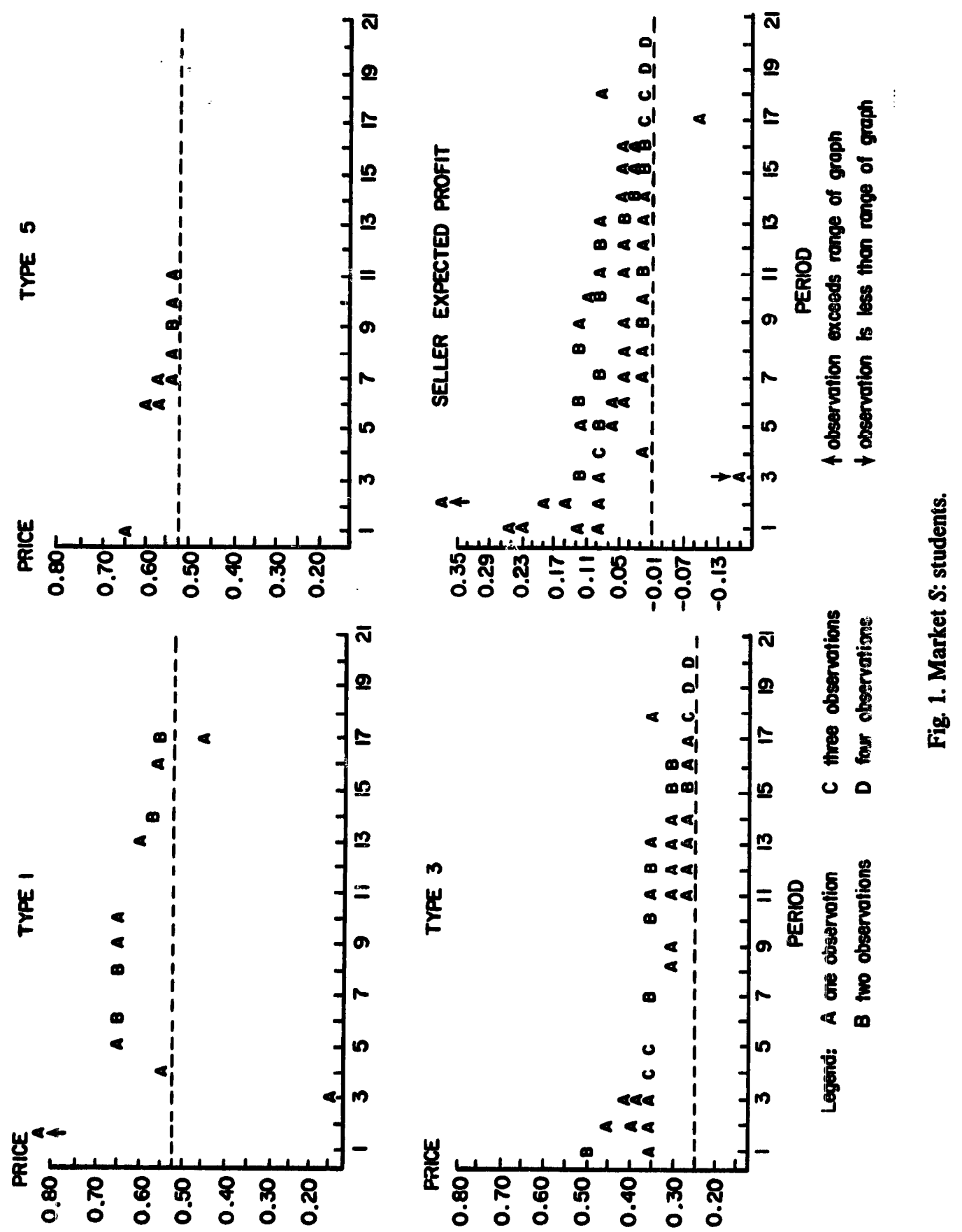

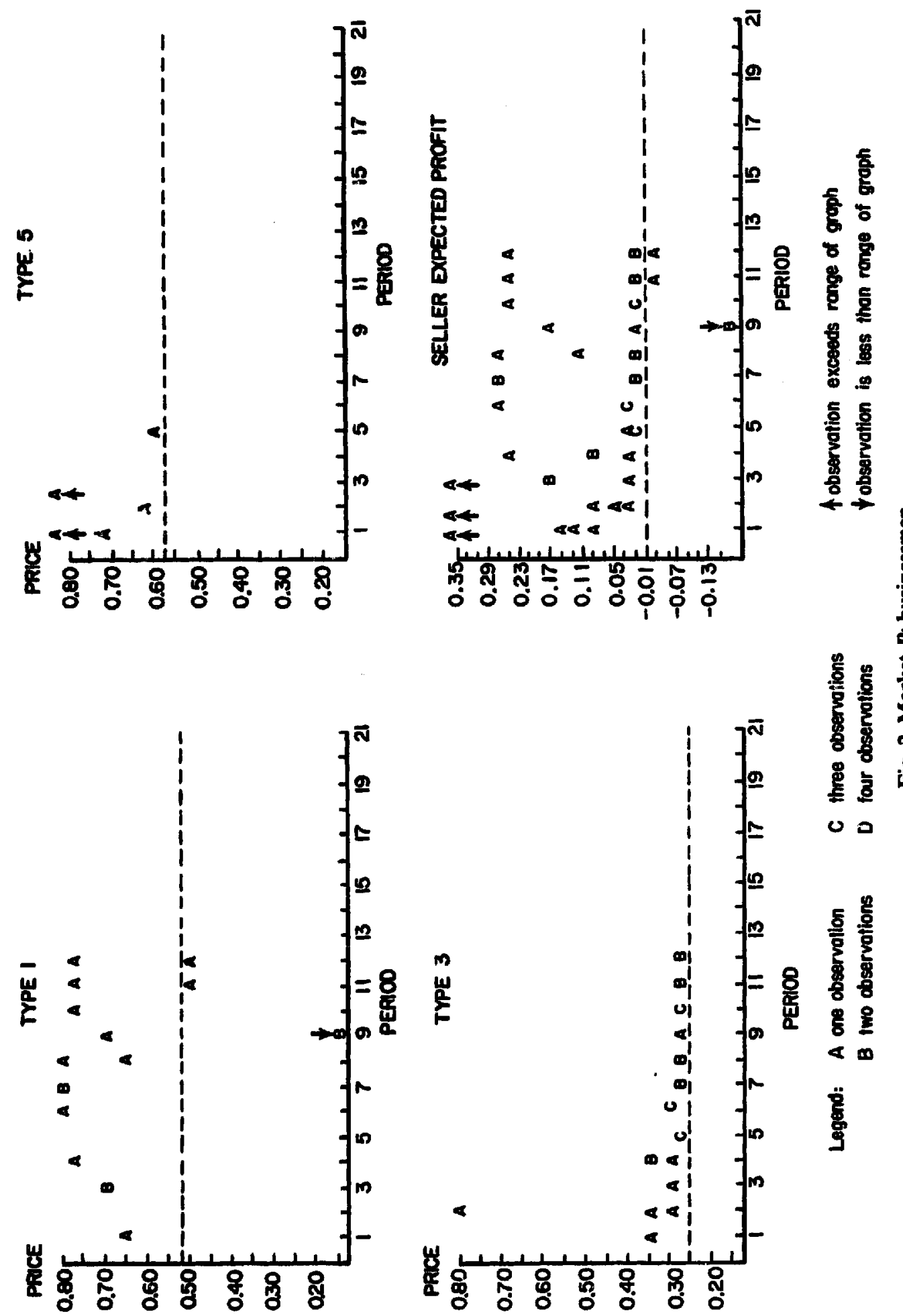
We empioy three performance measures to compare the sehavior observed in the two markets. The first performance measure deals with the quality levels or types provided and the prices of these levels. The raw data dealing with the quality levels provided and their prices is presented in the first three panels of figs. 1 and 2 for Markets $S$ and $B$, respectively. This data is summarized in table 2. Because of the insufficient number of certain quality levels that were traded, period-by-period comparisons cannot be made. Consequently, the observations in each market are pooled across trading periods and the statistics in this table report the mean and standard deviation for the two markets. Next, table 2 reports the $t$-statistics used to test the hypothesis of equal average prices in the markets. The final column of table 2 reports the $F$-statistics used to test the hypothesis of equal price variances in the markets.

The $t$-statistics in table 2 indicate that we are unable to reject the null hypothesis of equal average prices for the pairwise comparisons that were made between the two markets for each of the three quality levels or types. Inspection of the raw data in figs. 1 and 2, Markets $S$ and $B$, also supports this conclusion. For example, evaluating the type 3 units provided in both markets suggests that the means are similar to each other. However, the standard deviation of prices for each of the three types is consistently higher in the market with businessman subjects, Market $B$, than the market with student subjects, Market $S$. In particular, we are able to reject the null hypothesis of equal price variances in two of the three pairwise comparisons. Again, inspection of the raw data in figs. 1 and 2 supports this conclusion. For example, evaluating the type 5 units provided in both markets suggests that the variance is higher in Market $B$ than in Market $S$. It is also apparent

Table 2

Prices.

\begin{tabular}{|c|c|c|c|c|c|c|}
\hline \multirow[b]{2}{*}{ Type } & \multicolumn{2}{|l|}{ Mean } & \multicolumn{2}{|c|}{ Standard deviation } & \multirow[b]{2}{*}{ t-statistice } & \multirow[b]{2}{*}{ F-statistic ${ }^{\mathbf{b}}$} \\
\hline & $\begin{array}{l}\text { Market } \\
\text { S }\end{array}$ & $\begin{array}{l}\text { Maiket } \\
\text { B }\end{array}$ & $\begin{array}{l}\text { Market } \\
\text { S }\end{array}$ & $\begin{array}{l}\text { Market } \\
\text { B }\end{array}$ & & \\
\hline 1 & $\begin{array}{l}0.619 \\
(10)^{c}\end{array}$ & $\begin{array}{l}0.634 \\
(17)\end{array}$ & 0.217 & 0.236 & 0.17 & 1.18 \\
\hline 3 & $\begin{array}{l}0.358 \\
(28)\end{array}$ & $\begin{array}{l}0.315 \\
(26)\end{array}$ & 0.046 & 0.103 & -1.90 & $4.09^{\circ}$ \\
\hline 5 & $\begin{array}{l}0.571 \\
(10)\end{array}$ & $\begin{array}{c}1.064 \\
(5)\end{array}$ & 0.033 & 0.652 & 1.69 & $387.19^{d}$ \\
\hline
\end{tabular}

Null hypothesis of equal means.

'Null hypothesis of equal variances.

The numbers in parentheses are the number of observations of each type in each market.

${ }^{d}$ Reject $H_{0}, p=0.01$. 
from looking at the figures that the delivery of type 5 units occurred earlier in Market $B$ than in Market $S$.

The quality of service provided is also worthy of note. In the first twelve periods of sach market, there were 48 contracts. In the market with businessmen subjects, the quality level provided met or exceeded the due care standard less frequently than the quality level provided in the market with student subjects, i.e., 31 for Market $B$ versus 38 for Market $S$. However, performing a chi-square goodness-of-fit test, the null hypothesis of equal frequencies for the combined type 3 and type 5 deliveries in each market cannot be rejected at a significance level of 0.10 .

To aggregate across the different quality types and thus report and compare the data on a period-by-period basis, we computed sellers' expected profits in each market. This is our second performance measure. A summary of sellers' expected profits for the trading periods of the two markets is presented in table 3. The first four columns of the table report the mean and standard deviation of sellers' espected profit for each trading period (1 to 12), for each quartile (1-3, 4-6, etc.), for the entire market (1-12) and for the last eight periods (4-12). The final two columns of table 3 report $t$-statistics and $F$-statistics for testing the hypotheses of equal expected profit means and variances, respectively.

The conclusions based on sellers' expected profits in table 3 are consistent with the conclusions that were made based on the contract price data in table 2. Average expected profits in the market with businessmen subjects, Market $B$, are not generally different from average expected profits in the market with students, Market $S$. The null hypotheses of equal means can be rejected only once (period 5; out of the eightee. period-by-period and pooled interperiod comparisons that were made. Inspection of the sellers' expected profit per trade in each of the markets, the lower right paneis in figs. 1 and 2 , also supports this conclusion. That is, the average expected profits do not luok very different across Mai kets $S$ and $B$. The tests based on the variance of sellers' expected proifts also bear great similarity to those based on the contract price data reported in table 2. The variance of expected profits in Market $B$ with businessmen subjects was again higher than the variance observed in Market $S$ with student subjects in all but one trading period (period 5) and in all intraperiod poolings. Further, the null hypotheses of equal variances between these two markets is rejected at the 0.10 significance level in two-thirds of the somparisons, 12 times out of 18. Again, the raw data in the lower right panels of figs. 1 and 2 suggest that the variance of expected profits is higher in Market $B$ than in Market $S$.

Allocative efficiency is the third measure of performance used to evaluate the similarities and differences of the two markets. The efficiency measure used here is computed by comparing the expected surplus from an actual trade to the maximum expected surpius that was attainable through trade. 
Táble 3

jellers' expected profits.

\begin{tabular}{|c|c|c|c|c|c|c|}
\hline \multirow[b]{2}{*}{ Interval } & \multicolumn{2}{|l|}{ Mean } & \multicolumn{2}{|c|}{ Standard deviation } & \multirow[b]{2}{*}{ t-statistic ${ }^{a}$} & \multirow[b]{2}{*}{$F$-statistic ${ }^{b}$} \\
\hline & $\begin{array}{l}\text { Market } \\
\text { S }\end{array}$ & $\begin{array}{l}\text { Market } \\
\text { B }\end{array}$ & $\begin{array}{l}\text { Market } \\
S\end{array}$ & $\begin{array}{l}\text { Market } \\
\boldsymbol{E}\end{array}$ & & \\
\hline \multicolumn{7}{|l|}{ Period } \\
\hline 1 & 0.170 & 0.463 & 0.076 & $0.07 \overline{2}$ & 0.87 & $77.85^{d}$ \\
\hline 2 & .0 .220 & 0.180 & 0.171 & 0.242 & -0.27 & 2.01 \\
\hline 3 & -0.023 & 0.330 & 0.272 & 0.431 & 1.38 & 2.51 \\
\hline 4 & 0.073 & 0.120 & 0.035 & 0.093 & 0.95 & 7.02 \\
\hline 5 & 0.098 & 0.020 & 0.017 & 0.008 & $-8.19^{e}$ & 4.37 \\
\hline 6 & 0.090 & 0.098 & 0.035 & 0.115 & 0.12 & $10.44^{c}$ \\
\hline 7 & 0.063 & 0.140 & 0.034 & 0.139 & 1.09 & $16.58^{d}$ \\
\hline 8 & 0.078 & 0.100 & 0.051 & 0.116 & 0.36 & 5.24 \\
\hline 9 & 0.053 & -0.190 & 0.047 & 0.328 & -1.46 & $48.45^{e}$ \\
\hline 10 & 0.078 & 0.078 & 0.039 & 0.115 & 0 & 8.49 \\
\hline 11 & 0.045 & 0.065 & 0.033 & 0.126 & 0.31 & $14.33^{c}$ \\
\hline 12 & 0.065 & 0.065 & 0.036 & 0.126 & 0 & $11.54^{c}$ \\
\hline \multicolumn{7}{|l|}{ Quartile } \\
\hline $1-3$ & 0.123 & 0.324 & 0.204 & 0.452 & 1.41 & $4: 0^{d}$ \\
\hline $4-6$ & 0.087 & 0.079 & 0.030 & 0.089 & -0.28 & $9.07^{e}$ \\
\hline $7-9$ & 0.064 & $0.01 \%$ & 0.042 & 0.249 & -0.65 & $35.65^{\mathrm{e}}$ \\
\hline $10-12$ & 0.063 & 0.069 & 0.036 & 0.111 & 0.20 & $9.47^{e}$ \\
\hline \multicolumn{7}{|l|}{ Market } \\
\hline $1-12$ & 0.084 & 0.122 & 0.106 & 0.285 & 0.87 & $7.23^{\mathrm{e}}$ \\
\hline \multicolumn{7}{|c|}{ Last eight periods } \\
\hline $4-12$ & 0.071 & 0.055 & 0.037 & 0.163 & -0.58 & $19.64^{e}$ \\
\hline
\end{tabular}

Null hypothesis of equal means.

"Null hypothesis of equal variances.

'Reject $H_{0}, p=0.10$.

${ }^{d}$ Reject $H_{0}, p=0.05$.

'Reject $H_{0}, p=0.01$.

The expected surplus of a trade is the difference between the maximum amount a buyer will pay for a tirit and the seller's expected cost of providing that unit. In the markets considered here, the maximum amount a risk neutral principal should be willing to pay for a unit is his expected loss if he does not purchase, $72 \phi$, less the expected loss he faces for the unit purchased. For example, a risk neutral buyer would be willing to pay $72 \%-(0.05 \times 80 \%)-68 \%$ for a type 5 unit while it costs the seller $53 \notin$ to produce that unit. Thus, the expected surplus for a type 5 sale is $15 \phi$. A type 3 unit provicios the largest expected surplus of 30\%. Dividing the expected surpius from each trade by this maximum expected surplus, 30 , determines the allocative efficiency of that trade. Summing over the efficiencies per trade in a given period and 
dividing this amount by 4 (the maximum number of trades per period) gives the average market efficiency for the period. These mean efficiencies, their standard deviations, and the $t$-statistics and $F$-statistics necessary to test the hypotheses of equal means and equal variances, respectively, are reported in table 4.

Inspection of this table indicates that, based on allocative efficiency, few differences exist between the two markets. The hypothesis of equal mean allocative efficiencies can se rejected only twice [in period 6 and the first quartile of interperiod rooling, (1-3)] and the hypothesis of equal variances of allocative sificiencies can be rejected only in period 12 when Market $S$ attained $100 \%$ efficiency.

Table 4

Allocative efficiency.

\begin{tabular}{|c|c|c|c|c|c|c|}
\hline \multirow[b]{2}{*}{ Interval } & \multicolumn{2}{|l|}{ Mean } & \multicolumn{2}{|c|}{ Standard deviation } & \multirow[b]{2}{*}{ t-statisiic ${ }^{\mathrm{a}}$} & \multirow[b]{2}{*}{ F-statistic ${ }^{b}$} \\
\hline & $\begin{array}{l}\text { Market } \\
S\end{array}$ & $\begin{array}{l}\text { Market } \\
B\end{array}$ & $\begin{array}{l}\text { Market } \\
S\end{array}$ & $\begin{array}{l}\text { Market } \\
B\end{array}$ & & \\
\hline \multicolumn{7}{|l|}{ Period } \\
\hline 1 & 87.50 & 65.83 & 25.00 & 23.63 & -1.26 & 1.12 \\
\hline 2 & 90.83 & 87.50 & 18.33 & 25.00 & -0.22 & 1.86 \\
\hline 3 & 90.83 & 69.17 & 18.33 & 21.50 & -1.53 & 1.37 \\
\hline 4 & 90.83 & 90.83 & 18.33 & 18.33 & 0.00 & 1.00 \\
\hline 5 & 90.83 & 87.50 & 18.33 & 25.00 & -0.22 & 1.86 \\
\hline 6 & 56.67 & 90.83 & 7.70 & 18.33 & $3.43^{\mathrm{d}}$ & 5.67 \\
\hline 7 & 75.00 & 81.67 & 28.87 & 21.17 & 0.37 & 1.86 \\
\hline 8 & 69.17 & 81.67 & 21.50 & 21.17 & 0.83 & 1.03 \\
\hline 9 & 65.83 & 72.50 & 23.63 & 1833 & 0.45 & 1.66 \\
\hline 10 & 78.33 & 90.83 & 25.60 & 18.33 & 0.79 & 1.95 \\
\hline 11 & 87.50 & 81.67 & 25.00 & 21.17 & -0.36 & 1.39 \\
\hline 12 & 100.00 & 81.67 & 0 & 21.17 & 1.73 & $\infty^{c}$ \\
\hline \multicolumn{7}{|l|}{ Quartile } \\
\hline $1-3$ & 89.72 & 74.17 & 18.88 & 23.40 & $1.79^{\mathrm{c}}$ & 1.54 \\
\hline 49 & 79.44 & 89.72 & 21.97 & 18.88 & 1.22 & 1.35 \\
\hline $7-9$ & 70.00 & 70.61 & 22.83 & 18.88 & $1.0^{\circ}$ & 1.46 \\
\hline $10-12$ & 88.61 & 84.72 & 20.86 & 18.88 & -0.48 & 1.22 \\
\hline \multicolumn{7}{|l|}{ Market } \\
\hline $1-12$ & 81.94 & 85.63 & 22.02 & 19.95 & -0.03 & 1.17 \\
\hline \multicolumn{7}{|c|}{ Last eight periods } \\
\hline $4-12$ & 79.35 & 84.34 & 22.62 & 18.90 & 0.10 & 1.27 \\
\hline
\end{tabular}

'Ne!l hypothesis of equal means.

'Null hypothesis of equal variances.

'Reject $H_{0}, p=0.10$.

dReject $H_{0}, p=0.05$.

Reject $t_{0}, p=0.01$. 
We conclude this section with some anecdotal evidence about the sinilarities of these subject pools. In both markets, one seller sold a iype 1 at or near his production cost (between $6 \notin$ and 10ф) and thus failed to take into account his liability for a loss if one occurred. In both cases, the seller incurred a loss and took his liability into account when making subsequent offers. Also, in both markets, buyers accepted offers from sellers who sold them a unit for more than $80 \%$, even though a buyer could lose at most $80 \propto$ if he failed to make a purchase. Fortunately, buyers seemed to discover their 'error' as not one of them made such a purchase more than once. Thus, all subjects, whether students or businessmen, seem to exhibit similar tendencies to the extent that they make similar 'mistakes' when trading.

\section{Summary}

In this note we have presented some initial evidence on the use of businessmen as subjects in laboratory markets. This evidence indicates that the behavior observed in a laboratory market with 'real' businessmen is in many ways similar to that observed in a market with student subjects. Using three differeni performance measures (average prices, sellers' expected pronits and marisei filiciencies), we were, in general, unable to reject the null hypotheses regarding equal means between tive market with businessmen and the market with students. Using the price data and expected profit data, we found that the market with businessmen generally exhibited greater variance than the market with students. We are unable to determine whether this difference is due to subject pool variation or differences in the method of payment. Resolution of this difference will have to await further testing if additional opportunities to use businessmen in these markets arise.

\section{References}

Alpert, Bernard, 1967, Non-businessmen as surrogates for businessmen in behavioral experiments, Journal of Business 40, 203-207.

Brown, John P., 1973, Toward an economic theory of liability, Joumal of Legal Studies 2, 323349.

Burns, Penny, 1985, Experience and decision-making: A comparison of students and businessmen in a simulated progressive auction, in: V.L. Smith, ed., Research in experimental economics (JAI Press, Greenwich, CT).

Cunningham, William H., W. Thomas Anderson and John H. Murphy, 1974, Are students real people?, Journal of Business 47, 399-409.

DeJong, Douglas V., Robert Forsythe and Wilfred C. Uecker, 1985, The methodology of laboratory markets and its implications for agency research in accounting and auditing, Journal of Accounting Research 23, 753-793.

Hawkins, Del I., Gerald Albaum and Roger Best, 1977, An irvestigation of two issues in the use of students as surrogates for housewives in consumer behavior studies, Journal of Business 50, 216-222.

Kera, Inder P. and James D. Benson, 1970, Are students really poor subsiitutes for businessmen in behavioral research?, Journal of Marketing esearch 7, 529-532. 
Kormendi, Roger C. and Charles R. Plott, 1982, Committee decisions under alternative procedural rules: An experimental study applying a new non-monetary method of preference inducement, Journal of Economic Behavior and Organization 3, 175-195.

Plott, Charles R., 1979, The application of laboratory methods to public choice: in C.R. Russell, ed., Collective decision making: Applications from public choice theory, Resources for the Future (Washington, D.C.).

Plott, Charles R., 1982, Industrial organization theory and experimental economics, Journal of Economic Literature 20, 1485-1527.

Shavell, Steven, 1982, On liability and insurance, Bell Journal of Economics 13, 12n-132.

Shuptrine, F. Kelly, 1975, On the validity of using students as subjects in consumer behavior investigations, Journal of Business 48, 383-390.

Smith, Vernc L., 1976, Experimental economics: Induced value theory, American Economic Review 66, 274-279. 